\title{
Czech enterprises and the multidivisional form: Legitimation, legacies and structural choice ${ }^{*}$
}

\author{
Ed Clark $^{* *}$
}

This article examines the divisionalisation of organisational structures in three former state enterprises in the Czech Republic. The research findings suggest that this process has occurred in three broad phases and that structural change in the three enterprises has exhibited both common and divergent patterns. While considering the role of economic and institutional factors in the explanation of these different pathways, the main argument focuses on management motives behind the structural choices made, the socio-political responses to those choices from other social actors, and the significance of pre1989 organisational legacies.

Der vorliegende Artikel untersucht die Divisionalisierung dreier früherer Staatsbetriebe in der Tschechischen Republik. Die Untersuchungsergebnisse zeigen drei wesentliche Phasen der Umstrukturierung. Der Prozeß der Strukturveränderung in den drei Unternehmen weist sowohl Gemeinsamkeiten als auch Unterschiede auf. Bei der Erklärung dieser unterschiedlichen Transformationspfade werden ökonomische wie auch institutionelle Faktoren berücksichtigt. Die wesentliche Argumentation konzentriert sich aber auf entscheidungsbeeinflussende Motive des Managements, die Reaktion anderer gesellschaftlicher Kräfte auf diese Entscheidungen und die Bedeutung organisationaler Regelungen vor 1989.

Manuscript received: 10.9 .97 , accepted: 12.1 .98

** Ed Clark, born 1949, Principal Lecturer in Organisational Behaviour at Nottingham Business School, Nottingham Trent University. Major areas of research interest: changes in management practices, organisational structures and work behaviour in central and eastern Europe; changing nature of enterprise and community life in the same region.

Mail address: Department of Human Resource Management, Nottingham Trent University, Burton Street, Nottingham, United Kingdom

Tel.: +44 (0) 1159418418

Email: ed.clark@ntu.ac.uk 
Since 1990, the large state enterprises that used to dominate the socialist economies of Central and Eastern Europe (CEE) have undertaken fundamental processes of structural change. Organisational researchers have observed in CEE during this period the rise and spread of the multi-divisional form (MDF), which has been accepted by many practitioners as the antidote to the centralised functional hierarchy that had been the institutional blueprint of the command economy (see for example, Musil/Mares 1993; Bakacsi 1993; Cziria 1994; Hradecká 1994; Thirkell et al. 1995). In the West - particularly in the United States - evidence of the widespread adoption since the second world war of divisional principles in large organisations has led to a prolonged search for possible explanations. In general, the MDF has been seen to offer certain technical advantages and efficiencies for the prevailing business conditions of anti-monopolistic capitalism where large corporations are still expected to pursue strategies of growth.

As is often the case when examining Central and Eastern Europe, the researcher is left wondering how far the Western experience and Western accounts of that experience can help in understanding the processes of transitional economies and their constituent enterprises. Although the MDF has undoubtedly spread rapidly throughout the former communist region, corporate growth and product diversification within former state enterprises have not been the typical experiences (but see Peng/ Heath 1996). Indeed, large CEE enterprises have been subject to almost the opposite tendencies - decline in employment, reduction of product range, greater focus on core activities, and the shedding of many other activities that used to come under the enterprise umbrella (Soulsby/ Clark 1995). This paper, then, explores alternative explanations of the observed divisionalisation of industrial enterprises as part of their internal transformation, taking as its empirical basis findings from an in-depth study of three former state enterprises in the Czech Republic.

The findings are drawn from a research project which has traced in detail the progress of a number of mechanical engineering enterprises in Moravia. Since 1992, the author ${ }^{10}$ has spent a period of two weeks in each enterprise, during which over sixty senior and middle managers (as well as a few office and manual workers) were interviewed in depth about the past and about the post1989 changes taking place in the enterprises. These initial field research periods have been followed up with regular re-visits aimed at updating knowledge about

10 The research was conducted with my colleague Anna Soulsby, who has contributed to the development of the following arguments in a variety of ways. The author is also grateful to colleagues at the Faculty of Business and Management at the Technical University of Brno, without whose help and support this research would not have been possible. In particular, I thank Milos Kerkovsky, Milos Drdla, Hana Skyvarová, Mirka Cermáková, Thaddeus Mallya, Jan Hobl, Ales Vladik and Alena Kerkovská. 
the enterprises. The empirical materials have been further enhanced by work in the same enterprises on other related research topics. Altogether, about ninety managers have been interviewed and extensive formal and informal documents have been collected.

The three enterprises in question are all involved in the mechanical engineering industry of the Czech Republic, which had been of strategic economic significance under state socialism. Vols ${ }^{11}$ used to employ over 5,500 people in the small rural town of Volna and manufactured metallurgical products and heavy industrial machinery, $70-80 \%$ of which used to be exported to the former Soviet bloc countries and their third world client states. Following 1989, Vols has retained almost unchanged its product portfolio, but has reduced its workforce to about 4,500 by 1996 . Jesenické Strojírny also produces heavy engineering machines and plants for industrial clients, and was primarily oriented to the Soviet Union and the countries of the Council for Mutual Economic Assistance (CMEA). It is one of four major manufacturers in the medium-sized town of Jesenice, where its employment has diminished from 7,000 to $3,800^{12}$ in the first seven years of the transition. Both enterprises were privatised through the first wave of the mass voucher scheme, receiving private status in the first half of 1993.

Agstroj was also an enormous enterprise, employing over 10,000 people in the large industrial city of Stromesto, but it manufactures agricultural machinery that before 1989 was sold across the world for hard currency. In recognition of its economic contribution to the Czechoslovak command economy, Agstroj was the recipient during the 1980s of massive investment in its productive capacity. In 1993, the enterprise was "privatised" through a merger with its engine supplier, which had itself gone through the first mass privatisation wave. By 1996, it was still in majority held by the Consolidation Bank ${ }^{13}$, and employment had declined to less than 6,000.

In what follows, it is argued that divisionalisation in the enterprises has not merely been the technical adoption of a structural form, passively implemented as an economically optimal mechanism for managing a corporate strategy. Rather, it can be better understood as a structural choice enacted by senior decision makers to serve personal, professional and corporate-strategic interests, and as an ongoing process of social contestation involving other interested actors. These socio-political processes of divisionalisation are driven by the

11 All names of places and enterprises have been anonymised in order to preserve the confidentiality of respondents.

12 This includes the splitting-off as a separate entity of Jesenické Strojírny’s assembly plant.

13 Konsolidacní banka is a state-owned bank set up in 1991 to take on and consolidate the bad debts and poorly performing "assets" of the state sector. 
motives, values and preferences of the parties in question, drawing on contemporary and historical resources at their disposal. First the article considers some of the theory underlying these propositions, before looking at the evidence that can be adduced from the experiences of divisionalisation in the three enterprises. The paper ends with a brief set of conclusions for the study of the multidivisional form in Central and Eastern Europe.

\section{Divisionalisation: Structural Change and Social Process}

In his seminal work, supported by later refinements (e.g. Salter 1970; Channon 1973; Rumelt 1974; Wrigley 1974; Williamson 1975), Chandler (1962) argued that the key factor in explaining the adoption of the MDF in Western capitalism has been the technical superiority, and hence economic efficiencies, associated with a multi-divisional structure under conditions of product or market diversification. This has led to the famous dictum that structure always follows strategy, in recognition of the management benefits attributed to the MDF in relation to the problems created by manufacturing multiple, possibly unrelated, products under the same organisational roof. In similar vein, contingency arguments have pointed to the technical and economic problems created by organisational size and market diversity, and suggested that these difficulties may in principle be more efficiently and effectively managed through divisionalised structures (see for example, Mintzberg 1979:393ff; Child 1984:94-95; Palmer et al. 1993:102-103).

More recent American research has questioned the technical-economic argument as the sole or major explanation of the spread of the MDF, raising for consideration factors linked with institutional-isomorphic pressures and internal political, or strategic choice, processes (cf Fligstein 1985, 1991; Palmer et al. 1993). Following the theoretical leads of institutional theorists (cf. Meyer/ Rowan 1991; DiMaggio/ Powell 1991), various researchers of the Western MDF have attempted to assess whether the adoption of structural mechanisms is influenced by the need for organisations to operate in a socially legitimate manner rather than by some externally imposed constraint to be economically efficient. The organisational imperative for socially aware managers is thus to select organisational forms which meet the expectations of the business and management community and of wider groups of stakeholders (see Fligstein 1985, 1991; Palmer et al. 1993; and more generally Greenwood/ Hinings 1996), and this is thought to create the further tendency to acquire the fads and fashions of "progressive" management (cf. Huczynski 1993; Abrahamson 1996).

Another theoretical view expressed in the literature focuses on the ways in which important organisational decision makers exercise their power and declare their preferences in the processes which lead to the choice of a structural form such as the MDF. Both Fligstein (1985) and Palmer et al (1993) argue for the relevance of these essentially political factors, thereby building on the 
insights of Child $(1972,1997)$ into the role of strategic choice in organisational structuring and change. It is this view that is explored in more detail both theoretically, here, and empirically, below.

In conventional accounts, the adoption of the multi-divisional form is often described and analysed as an apparently unproblematic reorganisation of a company, a movement from an established, but technically sub-optimal, structural arrangement to another more efficient one ${ }^{14}$. The classical formulation that "structure follows strategy" implies that the rationales for choice of both strategy and structure are essentially driven by rational economic-technical considerations - e.g. the strategy of diversification is selected because of legal constraints on existing corporate growth in a single product/market; the MDF is then chosen as a technically efficient response to managing multiple products or markets. In this way, the motives of decision makers are narrowed by fiat to some technical concern with corporate profitability, market share or similar organisational goal. Moreover, in spite of the fact that structural changes may have major implications for the working environment of managers, employees and other stakeholders, the possible responses of such other social actors tend to be ignored as irrelevant, or treated as if they were unproblematic. With these implicit assumptions, it is easy to give the impression that structural change such as the introduction of the MDF is accepted as a shared organisational goal.

However, there are benefits to seeing the transformation of formal structures as, first, a social process which, second, takes place over a prolonged period of time, two issues which are more commonly raised in approaches to change management. From such a perspective, structural change involves questions not only of the selection of a relevant structural form, but also of the appropriate strategies of implementation to overcome resistance or conflict. Transformation, second-order change, quantum change, reorientation - or however the radical change is conceptualised (see, for example, Miller/ Friesen 1984; Tushman/ Romanelli 1985; Levy 1986) - necessarily demand a notion of change over time, including various possible "pathways" or "tracks", which may or may not end up with the desired structure being adequately installed (cf. Greenwood/ Hinings 1988; Laughlin 1991; Clark/ Soulsby 1995). In developing this perspective, structural change is understood less as a mechanistic response to inescapable economic or institutional demands in the external environment, and more as the social construction of actors with preferences, interests and the power to influence the structural outcome. In the words of two recent commentators:

14 This mechanistic process in many respects mimics the conventional economists' view of the macro-economic transition from hierarchical state socialism to a liberal market economy. 
"... the understanding of radical change requires more than an analysis of the institutional arena or sector. There must be a concern with the patterns of value commitments, power dependencies, interests and capacity for action within the organization." (Greenwood/ Hinings 1996: 1042; see also, for example, Wood 1979)

In this respect, the adoption of the MDF is an ongoing socio-political process, not the introduction of a technical object, a drawing or chart. The MDF is perceived in different ways by different social actors according to how it affects their stake in the organisation. These differential perceptions of and interests in the MDF lead to the exercise of power and authority in its promulgation by those managers whose interests and values are served by its institution; to social conflict over its implications for divisional or departmental life, such as the allocation of resources, rewards and work obligations; and to patterns of active and passive resistance to the design and meaning of the MDF when it does not fulfil the perceived needs of those without effective authority. These social processes, which create conditions for deviations from the planned structure and from its implementation, may be complemented and exacerbated by technical problems, such as the failure to provide the systems and procedures (e.g. information, costing and pricing systems) necessary to support the changes in question.

In responding to the new internal environments created by strategic and structural changes, managers and other employees make sense of the new conditions by drawing on various resources that are available to them by virtue of their experiences as organisational participants. Of particular importance, especially in circumstances that are changing rapidly and radically, are historical resources, which provide an anchor and reference point for individuals. In the words of an Agstroj director, "... the past is an iron shirt...”, and the legacies of management and of organisation define in part the prevailing patterns of preferences, values, motives and ways of perceiving and evaluating the organisational world.

All organisations have their own histories which influence in a variety of ways their later development. For post-communist managers, it is necessary to work not only in the context of the emergent market-economic world, but also within a commonly accepted organisational and managerial framework inherited from communist days - sets of traditions and values, physical and technological legacies, enterprise reputations etc. Enterprise managers have accumulated experiences of their enterprises and a stock of knowledge and recipes about the "proper ways" of handling recurrent problems. These organisational legacies are sedimentations of years of experience of everyday management life in particular enterprises which offer both constraints on what is seen to be possible, and resources that can be enacted to help accomplish new managerial tasks (Soulsby/Clark 1996). This argument affirms that processes of structural choice 
and change - such as the adoption of the MDF - do not come out of the blue. Rather, they are, at least in part, constructed from historically available ingredients of management and organisation which continue to affect strategic decision making and implementation via the taken-for-granted knowledge and practices of key powerful social actors. This thesis is strongly reminiscent of certain features of Stark's (1992) "path dependence" proposition.

"Actors who seek to move in new directions find that their choices are constrained by the existing set of institutional resources. Institutions limit the field of action, they preclude some directions, they constrain certain courses. But institutions also favor the perception and selection of some strategies over others." (Stark 1992:21).

\section{Empirical Patterns of Divisionalisation in the Czech Republic, 1990-1996}

In the following sub-sections, empirical case materials are drawn upon in order to explore the above issues in greater depth. Over the period from 1990-1996, none of the three enterprises took an easy and straightforward route to its preferred MDF, and I argue below that the actual pathways of divisionalisation can be understood in large part as products of the socio-political processes which occurred within the historical contexts of the particular enterprises. The general processes may be described in three stages. The first two stages correspond loosely with the period leading up to privatisation, 1990-1993, when the enterprises underwent very similar experiences of rapid decentralisation, followed by some degree of recentralisation. In the third stage, which occurred mostly after privatisation and leading up to 1996, the enterprises began to go down their own distinct paths.

\section{Decentralisation: the politics of strategic and structural choice}

In 1990, all three enterprises experienced rapid changes in their management and organisation. As the new senior management bodies took shape, small management teams were established to undertake strategic planning. In spite of espoused government policy, most senior managers believed that it was crucial to reorganise and restructure their enterprises before privatisation, and a high degree of pre-privatisation restructuring was uniform across all three enterprises. In each enterprise, strategic managers advocated and introduced a radical structural form, with more decentralised elements of the MDF. By designing structural units as cost-centres and profit-centres with greater degrees of autonomy and self-responsibility, senior managers eagerly embraced the Western model of the large corporation. The enthusiasm shown for the MDF in 
particular, and for Western models in genera ${ }^{15}$, was almost unbounded, and seemed to bear little relation to the technical relevance of the MDF for the enterprises. In fact, its adoption created technical problems, since the structure rapidly became too decentralised for the businesses and their environments (see below).

The question at this stage is why the senior managers in the three enterprises adopted the MDF with such enthusiasm, when its technical advantages in the prevailing circumstances were far from self-evident. To answer this question, it is necessary to consider the values, objectives and motives of senior managers and the nature of the problems they faced in 1990, when the first strategic and structural choices were made. The story of these managers and of enterprise management is one of both change and continuity. In the sample, only $19 \%$ of the "old guard" retained their directorate positions in the three enterprises. Yet $81 \%$ of those in post-1989 senior positions had been promoted from just the level below, and in 1989 had obviously been in the process of being groomed for the most senior levels (see Clark/ Soulsby 1996). Being either nomenklatura or aspiring nomenklatura managers, these men (there were no women) had joined the Communist Party and its organs and many had managed the enterprises through the socially and normatively difficult period of normalisation $^{16}$, which followed the suppression of the Prague Spring.

Being associated with the repressive communist state had personal and professional consequences. At a personal level, these individuals were seen as blemished, and they suffered from a deficit of social legitimacy inside the enterprise and within the larger local community, where typically employees and citizens paid mere lip-service to the regime and to its institutional representatives (Holy 1996: 27ff). Following the Velvet Revolution, local Civic Forum $^{17}$ groups were rapidly established in the enterprises and they began to take strong actions against a number of senior managers, thus creating intense personal insecurity for the existing management cadres. Their professional careers were further thrown into doubt by public debates about how to deal with the former Party officials, and the subsequent passing of the Screening (lustrace) Act (1991). This legislation prohibited former senior communists from holding important public office, which included directorships of state-

15 One strategic manager was so keen that after being interviewed he asked the researchers to send him information on matrix structures, a topic which had spontaneously become part of the interview discussion.

16 Normalisation here refers to the period following the Warsaw Pact invasion of 1968, when neo-Stalinist political and economic structures were reimposed on Czechoslovakia. The recentralising of political and economic control and the harsh punishments for disobedience led to strong popular dislike for the regime.

17 Civic Forum was the main anti-communist coalition during the Velvet Revolution of 1989. 
owned enterprises (see Wheaton/ Kavan 1992; Jeffries 1993). Given these local and national, social and legal processes, the legitimacy of state socialist managers was in serious dispute, both as individual citizens and, more especially, as career professional managers. It is contended here that within the three enterprises, which were in the main still directed by surviving former (aspiring) nomenklatura managers, the political process was substantively affected by their motives, including the felt need to transform their hitherto state socialist management credentials to those of bona fide market-economic managers.

In the immediate post-1989 context, the senior managers of the three enterprises made strategic and structural choices which they believed would enhance their chances of professional transformation and survival. While their main aim was to prepare the enterprises for the expected process of privatisation, in each case their strategic priority was to secure the interim survival of the enterprise. This strategy chimed well with their own personal goals of staking a legitimate claim to enterprise management. Given the wider talk in the communities about what to do with the ex-communists, the former nomenklatura realised that the main evidence of their own transformation to capitalist managers would come from their ability to demonstrate the health of the enterprise.

Drawing on the knowledge they had of existing large Western businesses, senior managers exhibited an implicit belief in the MDF as the appropriate model for large corporations, which would in turn, improve the chances of survival of their own enterprises. Some senior managers were unable to contemplate the possible failure of the MDF, and the degree of faith shown is illustrated by one director in Vols, who opined that the new structures would work because they "... had to work". In as much as they believed that the MDF offered a strategy for enterprise survival, their own hopes of managerial survival were also boosted.

The strong appeal of the MDF can be understood as part of an overall management strategy of re-legitimation. The MDF offered structures, systems and mechanisms that were not only directly related to known institutional models from the West - the ultimate source of values and validation for the new post-communist era; they were also a direct, explicit and clear refutation of the structures, systems and mechanisms upon which the now-discredited past had been constructed. By associating themselves with the market-economic MDF, and distancing themselves from command-economic functional form, the managers were allying themselves culturally and symbolically with the general prevailing expectations and values of marketisation, decentralisation, strategic autonomy, freedom, personal responsibility etc. (cf Child 1993). The MDF resonated with Western capitalist values and institutional concepts of modernness, which in turn brimmed with the one thing they perceived themselves as lacking in the post-1989 world - social legitimacy. 
In the first year or so after 1989, the structural choices of these professionally vulnerable managers showed all the hallmarks of a social group seeking wider social acceptance and legitimation. The early, enthusiastic adoption of the MDF supports this socio-political explanation of post-communist management behaviour. However, in spite of senior management faith in the structures, technical and social problems soon arose.

\section{Recentralisation: Technical problems and social resistance}

Introducing a new head office for strategic matters, each enterprise redefined a multitude of structural units as "divisions", implemented more delegated patterns of authority and responsibility between the centre and the units, and created more autonomy in the divisions and more competition between them. The radical divisionalisation that took place after 1989 led to two related kinds of control problem: technical control and social control.

Agstroj is essentially a single product business, yet in 1990 the strategic team devised a structure with ten divisions each operating as cost centres, with an intention of moving later to a profit-centred model. The substantially devolved responsibilities led to severe technical problems for the enterprise. In the words of one director:

... there were too many divisions and the span of control [of the General Director] was too great.

Jesenické Strojírny went much the same way, introducing sixteen units with divisional status and profit-centred responsibilities, far too many for the existing technical systems to cope with. Once again, having so many operating units reporting directly to him, the new General Director suffered serious problems of control. Furthermore, the accounting and general information support systems were slow, old fashioned, and poorly designed for controlling the MDF. In these conditions, the strategic head office could neither monitor divisions accurately nor have confidence in the reported performance of the decentralised units. Although Vols was more conservative in its restructuring, it too instigated a cost-centred multi-divisional structure which its management anticipated would move towards a profit-centred arrangement. Again, the management information systems provided inadequate assistance, leaving the centre structurally isolated from divisional decision making, and conceding to divisional and middle managers far more discretion than the senior managers had foreseen.

These technical weaknesses, the severity of which had been unforeseen by senior managers in their rush to divisionalise, were further revealed in and exacerbated through the diverse patterns of social response which the new structures elicited. The structures of the MDF generated an unfamiliar socioeconomic environment for both managers and employees. Senior and middle 
managers faced new expectations for their work and for their roles in the organisation, and the very basis of their relationships with other managers and other departments were altered. There is no doubt that some middle managers were simply afraid of the new demands:

The problem with the central plan was that everything was written and there was no place for "activity"... Sometimes [now], when I need to take a decision, I just feel confused... [Many managers] are unable to take decisions without getting confirmation from above. I worry so much about my responsibility that sometimes I cannot sleep. (Vols middle manager)

Such confusion and lack of confidence also led to conscious action against the new structures. In the past, middle managers had grown accustomed to an atmosphere of fear and mistrust, so that when asked for cost or other financial information, they used to conceal, withhold, bias or otherwise distort data to cast themselves and their colleagues in the best light. This routine fear of punishment continued to be reproduced in the early days of the MDF, thereby completely undermining the control processes necessary for a decentralised system.

The effects were cumulative. The centre could only inadequately monitor divisional performance by using informed guesswork to correct for inaccurate information coming through the formal systems, and the gap between centre and division in turn made it possible for divisional managers to exercise discretion in their own plants. A director at Jesenické Strojírny noted how

... each factory [using its new autonomy] effectively employed too many people. They protected people and services [and] overall it was inefficient.

In this respect, management decisions at divisional level were often expressions, not of the new hard-nosed market-economic rationality, but of a logic grounded in pre-1989 management values. A senior Agstroj director reflected upon this tendency:

Agstroj is soft on the individual [employee], which is typical... We are not used to saying "we don't want you from the 1st January"... There is still a lot of social thinking... [Hardness]... is not in the Czech culture.

While there is some evidence to locate such social thinking in the Czech value system, other managers saw the divisional protection of staff as a communist legacy:

[These managers]... are not red, but pink. (Another Agstroj director)

At Vols, there was a general agreement between senior managers, even at the level of head office, that the most important goal in the short to medium term was to defend the rights of employees and to look after their families, and they took strategic and operational decisions on social as well as market-economic grounds. A strategy manager at Jesenické Strojírny echoed these sentiments: 
[In the past, there was]... a certain pride, a loyalty and a sense of social responsibility; [these were reflected in]... the enterprise's social policy, [which] was in substance good.

However, the MDF did not induce an identical response from all managers in the enterprises. In spite of the general sharing of the social values referred to above, the MDF actually benefited some divisions and some operations rather than others, and the rule of expedience meant that the "winners" were more likely to support the new arrangements than the "losers". The more internally competitive and marketised the structure, the more it exposed some newly created divisions, whose poor economic performance had been concealed in aggregated enterprise information, as potential drags on the whole-enterprise performance. Hence, in 1990-1991, Vols' metallurgy division was a huge lossmaker, and the divisional head was among the most vociferous opponents of advancing the MDF to a fully-fledged profit-centred structure.

Meanwhile, the profit-centred MDF at Jesenické Strojírny served to aggravate and re-kindle inter-divisional conflicts that had smouldered for years under state socialism. Its most profitable turnkey business, requiring the coordination of the production schedules of the operating plants in order to ensure the construction of, say, a cement factory, was put in the hands of the Commercial Division. While the Production Divisions had to supply their products to Commercial for these integrated projects, they could only make profits from the production and delivery of less profitable single machines. The Production Divisions therefore felt not only that Commercial was able to put on excellent divisional performances on the back of their (i.e. Production's) hard work; but further that they were at the beck and call of Commercial, which had the full support of the General Director. Tense relations had always existed between these functions, but the marketised MDF exacerbated this structural conflict, led to passive resistance and a withholding of goodwill between the divisional managers.

In short, at most levels of management, the MDF was accepted as the right and proper structure for the transforming enterprises. However, in practice, the chosen form of divisionalisation created technical problems of head office control, threatened the confidence and the inherited social values of many managers, exposed latent unit weaknesses, revealed deep interdivisional conflicts through the use of competitive monitoring, and led to a good deal of resistance to the full force of divisional mechanisms and practices. By 1992, all three enterprises had stepped back from their initial attempts at the MDF, retrenching around more centralised, less competitive structures which conformed more closely to the capabilities of the information systems in place and to the values of the managers whose goodwill was necessary to make the structures work. Nevertheless, even in this process of retrenchment, the senior managers of all three enterprises remained faithful to their ideal of divisionalisation - the full holding company form, in which each division would 
become its own legal corporate entity within a looser umbrella of the parent company.

\section{Taking different paths: organisational legacies and the diversity of divisionalisation}

By the time they took on private status in the first half of 1993, each enterprise had undergone a very similar process, namely, the enthusiastic adoption of decentralised, divisionalised structures, which, for technical and social reasons, had been unsustainable in their initial forms. In the post-privatisation period, however, the three enterprises began to take divergent roads to divisionalisation. While Agstroj management was eventually forced to abandon its decentralising ambitions in favour of a recentralised functional form, Jesenické Strojírny proceeded rapidly - in spite of mentioned technical and social problems - to the full holding company form, and Vols remained broadly in a mixed cost-centre and profit-centre arrangement. Only Jesenické Strojírny achieved the common goal of installing a holding company structure, but the other two managements remained committed, formally or informally, to its realisation in the longer term. Having explained the pre-privatisation processes of divisionalisation in terms of managers' needs to reclaim legitimacy for their careers and the technical and social problems that arose within the three enterprises, it is now necessary to account for the diverse pathways followed by the enterprises. It will be argued that each enterprise was in some way a prisoner of its own historical legacies whereas these worked more or less as positive resources for the managers of Vols and Jesenické Strojírny, Agstroj managers' choices have been severely constricted by its state socialist past.

A huge injection of state investment during the 1980s had not only boosted Agstroj's strong industrial reputation within the Soviet world and beyond, but also increased its productive capacity in order to enhance its potential to earn hard currency. It is a strange irony that within years of acquiring this capacity, the demise of the command economy completely altered the enterprise's prospects within the ailing global agricultural industry of the 1990s. In the new circumstances, Agstroj has never been able to sell enough machines to reach the high break-even point determined by its new plant. In spite of formal privatisation through merger with its (privatised) engine supplier, Agstroj remained essentially a loss-maker, 70\% owned by the National Property Fund. In 1994, its assets and liabilities were "sold" to the state-owned Consolidation Bank to manage and billions of crowns of debt were effectively wiped out. Agstroj's experimentation with delegated authority and responsibility had been disastrous given the central need to minimise costs, and in 1995, Consolidation Bank insisted on appointing a new Production Director to whom all divisions were directly responsible: 
[The divisions]... had been decentralised following the pursuit of a holding company structure, [and it]... was not working. The organisation was felt to have become too decentralised - with duplication of resources and activities [and poor communication]. Agstroj had to be reorganised from scratch... They also needed tighter financial controls, so there had to be re-centralisation, a kind of tougher centralisation... (Agstroj Director)

The legacy of its high production capacity - its ultimate Achilles' heel - and the consequent inability to make profits have created a permanent financial crisis in the enterprise, which has effectively defined the economic limits of structural choice open to Agstroj managers. Its structural units may still be called divisions, but by 1996 they acted more like traditional plants.

While Agstroj serves to illustrate that technical-economic factors have an important role in determining the boundaries within which structural choice may operate, Jesenické Strojírny, which advanced rapidly to the holding company form, demonstrates the way in which powerful managers can enforce their structural preferences in spite of the existence of opposition. Technically the activities of Jesenické Strojírny called for structures which emphasised cooperation and coordination between plants, rather than interdivisional competition and rivalry, yet the senior managers persisted with their espousal of an internal market model. It is possible to trace this senior management fervour for the holding company structure back to the enterprise's history.

Jesenické Strojírny has a progressive reputation, deriving in large part, according to respondents, from the open attitudes and behaviour of the pre-1989 General Director who had ruled the enterprise for more than 20 years. In line with politico-economic reforms during the late 1960s, the enterprise had experimented with decentralised MDF-style structures, but had had to abandon such "modernising" concepts in the early 1970s, when normalisation began to take hold in the economic sphere. When the new General Director, who had himself been a reforming middle manager during the late 1980s, appointed as his Strategy Director the very person who had been responsible for the structural experiments of the 1960s, it came as little surprise to find the senior management team advocating the adoption of the MDF with the goal of moving as rapidly as possible to a holding company structure. The opposition by key divisional managers had restrained the divisionalisation process before privatisation, but once the senior managers had gained the confidence and support of the new owners in 1993, the strong emotional commitment of key managers to the holding company was enough to drive forward its realisation. In January 1995, when the new legal form was officially implemented, it was as if some inevitable historical process had eventually unfolded within the enterprise.

The case of Vols falls between the other two enterprises, as during the 1990s it has maintained a commitment to a moderately decentralised MDF, steering a steady line between the felt need to become more modern, more Western and 
more market-oriented in its structures, and the maintenance of its social legacies. Vols was established and built up during the 1950s as a conscious part of Czechoslovakia's social and economic policies. The enterprise and the local community of Volna gained hugely because of their roots in communist policies and the strength of their links with the National Communist Party. Managers who joined Vols had been strongly committed to the social role of the enterprise - as shown above - and these commitments and values have continued to circumscribe the structural decision making in the enterprise. Social thinking has tempered the willingness of managers to introduce any changes into the enterprise that might damage its social and economic relationship with Volna. Like Jesenické Strojírny, after privatisation and with the support of the new owners, Vols' senior managers continued to operate within decision making boundaries set by their own motives and values, but the traditions of Vols predisposed its management towards a more gradualist approach to divisionalisation.

\section{Conclusions}

By examining the actual processes of divisionalisation within three enterprises in the Czech Republic, it has been possible to explore a number of explanations for the paths adopted. The nature of the argument has been shaped by consideration of the three factors which have emerged in the literature that has extended the pioneering work of Chandler (1962): viz. technical-economic factors, institutional factors and political (strategic choice) factors. However, the theoretical presumption has been that all structural changes are ultimately the choices of senior managers in the enterprises, and this stance has informed the types of explanation proposed. The research findings have highlighted the role of personal and professional motives in the structural choices of the powerful social actors in the enterprises and have pointed to the need to consider divisionalisation as a socially contested process circumscribed by external economic and institutional factors and by historical legacies. The evidence from the enterprises suggests that divisionalisation has passed through three stages.

The first two stages emphasise similarities in organisational experience, which, it is contended, relates to the initial motives and anxieties of the post-communist managers, many of whom had been deeply implicated in enterprise management under the communist regime. Concerned with their personal and professional legitimacy, senior managers made structural choices which they estimated would optimise the chances of enterprise survival, and thus improve their own claims to being bona fide market-economic managers. The MDF was not only based on highly credible Western models, but it also embodied and symbolised the critical values of the emergent society - freedom, devolved responsibility, private accountability, decentralisation etc. The enthusiastic advocacy of these principles thus served to enhance managers' credentials in the eyes of 
organisational stakeholders, who included not only the employees and the liberal-economic government, but also would-be shareholders and owners. The strength of support for the holding company concept, even where it was a technical mismatch with product-market or financial realities, may be a direct indicator of the severity of the problem of managerial legitimacy faced in the early post-1989 period.

Following implementation of some variant of the MDF, each enterprise faced technical and social problems of control. The latter were particularly important, and the MDF could be seen to create or make manifest personal anxieties and inter-unit conflicts. During this second stage of contestation, each enterprise withdrew to some degree from the decentralised model it had initially adopted. During the final stage, which followed privatisation, the enterprises began to follow their own distinctive pathways to divisionalised, decentralised forms. The discussion of these findings dwelled particularly on continuing influence of specific enterprise histories and legacies.

To conclude, it is possible to make a judgement about the relative importance of, or the respective roles played by, technical-economic factors, institutional factors and strategic choice processes in the adoption of the multi-divisional form. The evidence and interpretation offered here suggests that external economic factors are best understood as playing a significant role in defining the limits of management choice. Technical-economic factors seemed to establish the boundaries beyond which structures had to become more centralised in order to assert firm control over organisational activities, but within which managers could enjoy a broad degree of discretion to be able to pursue their own preferences with respect to organisational design. Institutional pressures emanated from society at large with its general normative expectations about decentralisation, private responsibility and autonomy; and, more concretely, from the business environment of internationally available and socially acceptable patterns or blueprints regarding appropriate structural forms for a post-communist, market-economic organisation. The MDF provided enterprise managers with a socially legitimate design that fulfilled these general and specific institutional expectations. However, from the detailed cases of divisionalisation reported here, it is argued that the influence of both technicaleconomic and institutional contextual factors has been crucially mediated by the intervention of human agency. Divisionalisation can therefore be understood as a process which is socially constructed by significant organisational actors, who exercise power within a set of constraints and opportunities afforded by contemporary and historical circumstances.

\section{References}

Abrahamson, E. (1996): Management fashion, in: Academy of Management Review 21(3), 254-285. 
Bakacsi, G. (1994): Organisational transition - management legacy, in: Makó, C./ Novoszát, P. (Eds.), Convergence versus Divergence: The Case of the Corporate Culture, Budapest: Communication and Consultation Co, Ltd, 37-45.

Chandler, A. D. (1962): Strategy and Structure: Chapters in the History of the Industrial Enterprise, Cambridge, Massachusetts: MIT Press.

Channon, D. F. (1973): The Strategy and Structure of British Enterprise, London: MacMillan.

Child, J. (1972): Organizational structure, environment and performance: the role of strategic choice, in: Sociology 6(1), 1-22.

Child, J. (1984): Organization: a Guide to Problems and Practice (2nd edn), London: Paul Chapman.

Child, J. (1993): Society and enterprise between hierarchy and market, in: Child, J./ Crozier, M./ Mayntz, R./ et al., Societal Change Between Market and Organization, Aldershot: Avebury, 203-226.

Child, J. (1997): Strategic choice in the analysis of action, structure, organizations and environment: retrospect and prospect, in: Organization Studies, 18(1), 43-76.

Clark, E./ Soulsby, A. (1995): Transforming former state enterprises in the Czech Republic, in: Organization Studies 16(2), 215-242.

Clark, E./ Soulsby, A. (1996): The Re-formation of the managerial elite in the Czech Republic, in: Europe-Asia Studies 48(2), 285-303

Clark, E./ Soulsby, A. (1998): Organization, Management and Transformation: institutional Change in the Czech Republic, London: Mansell (in press).

Cziria, L. (1995): The Czech and Slovak Republics, in: Thirkell, J./ Scase, R./ Vickerstaff, S. (Eds.), Labour Relations and Political Change in Eastern Europe, London: UCL Press, 61-80.

DiMaggio, P./ Powell, W. (1991): The iron cage revisited: institutional isomorphism and collective rationality, in: Powell, W./ DiMaggio, P. (Eds.), The New institutionalism in Organizational Analysis, Chicago: University of Chicago Press, 63-82.

Fligstein, N. (1985): The spread of the multidivisional form among large firms, 1919-1979, in: American Sociological Review 50 June, 377-91.

Fligstein, N. (1991): The structural transformation of American industry: an institutional account of the causes of diversification in the largest firms, 1919-1979, in: Powell, W./ DiMaggio, P. (Eds.), The New Institutionalism in Organizational Analysis, Chicago: University of Chicago Press, 311-336.

Greenwood, R./ Hinings, C. R. (1988): Organizational design types, tracks and the dynamics of strategic change, in: Organization Studies 9(3), 293-316.

Greenwood, R./ Hinings, C. R. (1996): Understanding radical organizational change: bringing together the old and the new institutionalism, in: Academy of Management Review, 21(4), 1022-1054.

Holy, L. (1996): The Little Czech and the Great Czech Nation: National Identity and the Post-Communist Social Transformation, Cambridge: Cambridge University Press. 
Hradecká, I. (1994): Special features of Czech privatized enterprises with foreign capital participation, in: Vlácil, J./ Hradecká, I./ Mazálková, I., Large-Scale Privatization: Social conflict and Consensus, Prague: Institute of Sociology Working Papers, Academy of Sciences in the Czech Republic.

Huczynski, A. (1993): Explaining the succession of management fads, in: International Journal of Human Resource Management 4(2), 443-63.

Jeffries, I. (1993): Socialist Economies and their Transition to the Market, London: Routledge.

Laughlin, R. (1991): Environmental disturbances and organizational transitions and transformations: some alternative models, in: Organization Studies 12(2), 209-232.

Levy, A. (1986): Second-order planned change: definition and conceptualization, in: Organizational Dynamics 15(1), 5-20.

Meyer, J./ Rowan, B. (1991): Institutionalized organizations: formal structure as myth and ceremony, in: Powell, W./ DiMaggio, P. (Eds.), The New Institutionalism in Organizational Analysis, Chicago: University of Chicago Press, 41-62.

Miller, D./ Friesen, P. (1984): Organizations: A Quantum View, Englewood Cliffs, NJ: Prentice-Hall.

Mintzberg, H. (1979): The Structuring of Organizations, Englewood Cliffs, NJ: PrenticeHall.

Musil, L./ Mares, P. (1993): The 'entitlement mentality' and legitimacy of privatization in industry, in: Working Papers of the Philosophy Faculty, G 35, Brno: Masaryk University.

Palmer, D./ Jennings, P./ Zhou, X. (1993): Late adoption of the multidivisional form by large U.S. corporations: institutional, political and economic accounts, in: Administrative Science Quarterly, 38, 100-131.

Peng, M./ Heath, P. (1996): The growth of the firm in planned economies in transition: institutions, organizations, and strategic choice, in: Academy of Management Review, 21(2), 492-528.

Rumelt, R. (1974): Strategy, Structure and Economic Performance, Boston: Harvard Business School.

Salter, M. (1970): Stages of corporate development, in: Journal of Business Policy Spring: 23-37.

Soulsby, A./ Clark, E. (1995): Privatisation and the restructuring of enterprise social and welfare assets in the Czech Republic, in: Industrial Relations Journal 26(2), 97-109.

Soulsby, A./ Clark, E. (1996): The emergence of post-communist management in the Czech Republic, in: Organization Studies 17(2), 227-247.

Stark, D. (1992): Path dependence and privatization strategies in east central Europe, in: East European Politics and Societies 6(1), 17-54.

Thirkell, J./ Scase, R./ Vickerstaff, S. (1995): Changing models of labour relations in eastern Europe and Russia, in: Thirkell, J./ Scase, R./ Vickerstaff, S. (Eds.), Labour Relations and Political Change in Eastern Europe, London: UCL Press, 7-29. 
Tushman, M./ Romanelli, E. (1985): Organizational evolution: a metamorphosis model of convergence and reorientation, in: Cummings, L./ Staw B. (Eds.), Research in Organizational Behavior, Greenwich, CT: JAI Press, 171-222.

Wheaton, B./ Kavan, Z. (1992): The Velvet Revolution: Czechoslovakia, 1988-1991, Oxford: Westview.

Williamson, O. (1975): Markets and Hierarchies: Analysis and Anti-Trust Implications, New York: Free Press.

Wood, S. (1979): A reappraisal of the contingency approach to organization, in: Journal of Management Studies 16(3), 334-354.

Wrigley, L. (1974): Diversification and Divisional Autonomy, Boston: Harvard Business School. 